\title{
N-Terminal Pro-brain Natriuretic Peptide and Cardiovascular Adaptations in Monochorionic Diamniotic Twins
}

\author{
Kazumichi Fujioka ${ }^{1,2 *}$ and Hideto Nakao ${ }^{1}$ \\ ${ }^{1}$ Department of Neonatology, Hyogo Prefectural Kobe Children's Hospital Perinatal Center, Kobe, Japan \\ ${ }^{2}$ Department of Pediatrics, Division of Neonatal and Developmental Medicine, Stanford University School of Medicine, Stanford, CA, USA
}

\begin{abstract}
Monochorionic diamniotic pregnancies are associated with adverse perinatal outcomes, including neonatal death and handicaps. Additionally, postnatal circulatory collapse has been suggested to be associated with a poor perinatal outcome, but this has not been fully investigated. We have assessed postnatal cardiac adaptations of monochorionic diamniotic twins by measuring $\mathrm{N}$-terminal pro-brain natriuretic peptide, a precursor of brain natriuretic peptide. We observed the following findings. First, monochorionic diamniotic twins with twin-to-twin transfusion syndrome show an increased cardiac load at birth, and they require complete intensive care for both twins for postnatal circulatory collapse, which is alleviated by fetoscopic laser photocoagulation. Second, monochorionic diamniotic twins with selective intrauterine growth restriction show mildly increased cardiac load at birth compared with twin-to-twin transfusion syndrome, and most require intensive care for both twins because of poor cardiovascular adaptations. Third, the reason for the increased cardiac load in these monochorionic diamniotic twins is unbalanced blood transfusion via intertwin vascular anastomoses, as shown by a comparative study between monochorionic diamniotic and dichorionic diamniotic twins with selective intrauterine growth restriction. Further study is necessary to determine other high risk monochorionic diamniotic twin groups. Additionally, a novel therapeutic strategy, including fetal therapy, is mandatory to prevent postnatal cardiovascular collapse in monochorionic diamniotic twins.
\end{abstract}

Keywords: N-terminal pro-brain natriuretic peptide; Monochorionic diamniotic twin; Cardiac load; Vascular anastomoses; Twin-to-twin transfusion syndrome; Single intrauterine growth restriction; Neonate

Abbreviations: MD: Monochorionic Diamniotic; DD: Dichorionic Diamniotic; TTTS: Twin-to-Twin Transfusion Syndrome; sIUGR: selective Intrauterine Growth Restriction; IUGR: Intrauterine Growth Restriction; NT-proBNP: N-terminal pro-brain Natriuretic Peptide; BNP: Brain Natriuretic Peptide; FLB: Fetoscopic Laser Photocoagulation

\section{Introduction}

Twin pregnancies are associated with adverse perinatal outcomes, including neonatal death and handicaps [1]. With respect to chorionicity, monochorionic twin pregnancies are less frequent than dichorionic twin pregnancies, and are associated with higher morbidity and mortality [2,3]. Monochorionic Diamniotic (MD) twins have placental vascular anastomoses, but this is not found in Dichorionic Diamniotic (DD) twins, which can cause intertwin blood transfer to different degrees [4-7]. Twin-to-Twin Transfusion Syndrome (TTTS), the severest complication of MD pregnancies, occurs from a disrupted balance of intertwin blood transfer, or unidirectional twin-to-twin blood transfusion [8-10]. TTTS occurs in approximately $15 \%$ of MD pregnancies and has a poor fetal prognosis, which leads to hypervolemia, polyuria, and polyhydramnios in the recipient, and hypovolemia, oliguria, and oligohydramnios in the donor $[6,9,11]$. Fetal cardiac dysfunction in recipients of TTTS has been studied, and has mainly been assessed by fetal echocardiography [12-15] or amniotic Brain Natriuretic Peptide (BNP) concentrations [16-18]. An association between fetal cardiac dysfunction and poor perinatal outcome has been suggested $[19,20]$. In particular, we have observed MD twins with TTTS frequently developed postnatal circulatory collapse, which required intensive treatment [10]. However, this situation has not been thoroughly investigated by others. The pathophysiology of this cardiovascular disturbance in MD twins with TTTS has not been fully clarified, but renin-angiotensin-aldosterone system involvement has been proposed by Mahieu-Caputo et al. [21].
They found that both MD twin pairs with TTTS have high renin cord blood levels. In donor twins, circulatory volume is reduced by shunt flow to the recipient, which induces renin upregulation. Additionally, in the recipient twin, circulatory volume is increased by shunt flow from the donor, which induces renin downregulation. Furthermore, hyper-secreted renin is transferred from donor to recipient via placental anastomoses, and then the recipient suffers from high renin levels in spite of volume overload, aggravating congestive heart failure $[21,22]$. However, this mechanism is not sufficient to completely explain the poor postnatal cardiac adaptations in both MD twins with TTTS, especially for the donor twin. Some other possible mechanisms for postnatal cardiovascular disturbance in donor twins have been proposed, such as pressure overload induced by renin-angiotensinaldosterone activation [6], hypoxemia resulting from hypovolemia that could affect cardiac function [23], intrauterine growth restriction in the smaller twin that is associated with increased cardiac load [24], and fetal anemia caused by intertwin blood transfusion, which also induces cardiac workload due to the hyperdynamic state [25].

Recently, a couple of specific MD twin groups, who did not meet Quintero's criteria of TTTS, but had poor perinatal outcomes, were described, including selective Intrauterine Growth Restriction (sIUGR) [26,27], twin anemia polycythemia syndrome $[28,29]$,

*Corresponding author: Kazumichi Fujioka, M.D. Ph.D., Department of Pediatrics, Division of Neonatal and Developmental Medicine, Stanford University School of Medicine, 300 Pasteur Drive, Grant BIdg, Rm S230, Stanford, CA 94305-5208; E-mail: fujiokak@med.kobe-u.ac.jp, fujiokak@stanford.edu

Received December 23, 2013; Accepted Janaury 09, 2014; Published Janaury 11, 2014

Citation: Fujioka K, Nakao H (2014) N-Terminal Pro-brain Natriuretic Peptide and Cardiovascular Adaptations in Monochorionic Diamniotic Twins. J Neonatal Biol 3 : 124. doi:10.4172/2167-0897.1000124

Copyright: ( 2014 Tsai HC, et al. This is an open-access article distributed under the terms of the Creative Commons Attribution License, which permits unrestricted use, distribution, and reproduction in any medium, provided the original author and source are credited. 
and acute peripartum twin-twin transfusion syndrome [30,31]. We previously reported an unusual case of preterm MD twins who did not meet the criteria of the above three entities [32]. They suffered from circulatory collapse soon after birth and needed intensive treatment. Intraventricular hemorrhage and severe retinopathy of prematurity with retinal detachment in both twins occurred [32]. Among these non-TTTS MD twins, an increasing number of studies have shown a significant association between sIUGR and adverse perinatal outcomes $[26,33,34]$, and cardiac complications were suggested as the cause of these adverse outcomes [27]. However, the postnatal cardiovascular adaptations of these patients have not been fully investigated, because most of the MD pregnancies researches were done by obstetrician, not neonatologists who were engaged in neonatal circulatory management.

We are interested in postnatal cardiac adaptations of MD twins and have attempted to assess cardiac function by using $\mathrm{N}$-terminal proBrain Natriuretic Peptide (NT-proBNP) measurements in combination with other diagnostic modalities. NT-proBNP is a precursor of $\mathrm{BNP}$, and is a convenient and objective diagnostic marker of cardiac dysfunction in neonates, as well as in adults and children $[35,36]$. Interestingly, an increase in serum NT-proBNP levels in the late stage of twin pregnancy was reported [37]. Preferably, NT-proBNP is derived from the fetus itself, and does not reflect transplacental exchange of maternal NT-proBNP [38]. Moriichi et al. showed that high BNP levels in the umbilical cord blood and amniotic fluid are a predictive factor for cardiac dysfunction and hypotension soon after birth in singleton neonates [39]. Therefore, we propose that NT-proBNP levels at birth would reflect intrauterine cardiac load and be a predictive marker for postnatal circulatory collapse in MD twins. Echocardiography is the most frequently used technique to evaluate cardiac function in high risk MD pregnancies, but the accuracy of assessment may depend on the examiner's experience and the fetal position [40]. Therefore, we adopted serum NT-proBNP as a conventional biomarker of cardiac load in clinical practice in combination with echocardiography as a complementary method.

Kobe Children's Hospital is a tertiary center in Hyogo Prefecture and manages more than 100 complicated twin pregnancies per year. In this hospital, we have used NT-pro BNP as a neonatal cardiac biomarker for premature and complicated newborns for years. In addition, when we attempted brief literature review to identify articles relating cardiovascular adaptations in MD twins and NT-pro BNP, only a couple of literatures were found except ours [18,37,41]. In this narrative review, we briefly describe the postnatal circulatory status in MD twins based on our recent observations.

\section{Neonatal Nt-Pro BNP Levels in MD Twins with TTTS}

The fact that MD twins with TTTS have a poor pregnancy outcome is well known, but there are few reports regarding postnatal cardiac adaptations. With regard to assessment of NT-pro BNP, there is a positive correlation between TTTS staging and amniotic NTproBNP levels [41], as well as a correlation between the severity of cardiomyopathy in TTTS recipients and amniotic NT-proBNP levels [18]. However, no reports have assessed postnatal cardiac function in MD twins with TTTS using NT-proBNP, except for our previous study [10]. In our previous study, we found increased levels of NT-pro BNP at birth in recipient and donor twins of TTTS, using MD twins with TTTS treated by Fetoscopic Laser Photocoagulation (FLP) as controls [10]. Theoretically, MD twins with TTTS treated by FLP have similar intrauterine hemodynamics to DD twins, because DD twins do not have intertwin vascular anastomoses. We found the serum NT-proBNP levels at birth in MD twins with TTTS were significantly higher than those in MD twins with TTTS treated by FLP $(29,900 \mathrm{pg} / \mathrm{ml}$ [range, $7300-77,900 \mathrm{pg} / \mathrm{ml}$ ] vs. $1425 \mathrm{pg} / \mathrm{ml}$ [range, $466-9560 \mathrm{pg} / \mathrm{ml}$ ], $\mathrm{P}<0.001$, Figure 1A). Additionally, serum NT-proBNP levels between larger and smaller co-twins were significantly correlated $(r=0.75, P=0.03$, Figure $2 \mathrm{~A}$ ). This suggests that both donor and recipient MD twins with TTTS suffer from significant cardiac load soon after birth. Eliminating the vascular anastomoses by FLP turned out to be efficacious, even for reducing the postnatal cardiac load of MD twins with TTTS, which is consistent with reports evaluating the effect of FLP on postnatal outcomes [42,43].

\section{Neonatal Nt-ProBNP Levels in MD Twins with sIUGR}

Selective intrauterine growth restriction is a newly recognized complication in MD twins accompanied by poor fetal outcome, where only one of the twins develops intrauterine growth restriction. The definition of sIUGR proposed by Gratacos was recently accepted, that estimated fetal weight is below the 10th percentile in the smaller twin at 18 to 26 weeks and does not meet the criteria of TTTS [26]. The incidence of sIUGR is approximately $11-14 \%$ in all monochorionic twin pregnancies, and this is associated with a poor pregnancy outcome, including perinatal death or neurological morbidity for both twins $[26,33,34]$. We and others have proposed that postnatal cardiac complications are a cause of such adverse outcomes in monochorionic twin pregnancies with sIUGR $[6,27,44,45]$. For the purpose of clarifying postnatal cardiovascular adaptations of sIUGR, we carried out an observational study of NT-proBNP levels at birth, comparing MD twins with sIUGR and those without. Consequently, we found that the serum NT-proBNP levels at birth in MD twins with sIUGR were significantly higher than those in MD twins without sIUGR (4520 pg/ $\mathrm{ml}$ [range, $529-62,400 \mathrm{pg} / \mathrm{ml}$ ] vs. $1270 \mathrm{pg} / \mathrm{ml}$ [range, 274-38,700 pg/ $\mathrm{ml}$ ], $\mathrm{P}<0.0001$, Figure 1B).

In addition, the incidence of cardiac dysfunction was significantly higher in the sIUGR group than in the control group. In addition, serum NT-proBNP levels between smaller and larger co-twins were significantly correlated $(r=0.87, \mathrm{P}<0.0001$, Figure $2 \mathrm{~B})$. These significant correlations were found in the sIUGR group $(\mathrm{r}=0.85, \mathrm{P}<0.0001)$ and the control group $(\mathrm{r}=0.84, \mathrm{P}<0.0001)$. Most importantly, sIUGR was independently associated with NT-proBNP levels at birth after multivariate linear regression analysis [46]. According to these observations, we currently consider that even MD twins without TTTS should be monitored carefully for circulatory collapse soon after birth, if they show specific phenotypes during the fetal period.

\section{Effect of Vascular Anastomoses on Neonatal Nt- ProBNP levels}

Imbalance of intertwin blood transfusion via vascular anastomoses in MD twins with sIUGR should be a powerful contributor to cardiac load and increased NT-proBNP levels, as well as to the mechanisms in TTTS. However, other factors could affect BNP or NT-proBNP levels, including prematurity [47], asphyxia [48], fetal anemia [25], and IUGR [24], as mentioned above. In particular, IUGR causes redistribution of circulation, diverting oxygenated blood from other tissues to sustain growth of the brain, by shifting cardiac flow [49]. Leipala et al. reported that IUGR is associated with an alteration in early hemodynamic adaptation in low birth weight infant [24]. By consideration of their result, it was necessary to use twins with sIUGR, but without vascular anastomoses, as a negative control. This was necessary to determine the effect of vascular anastomoses on NT-proBNP levels in MD twins with sIUGR. Following this study, we planned to compare NT- 

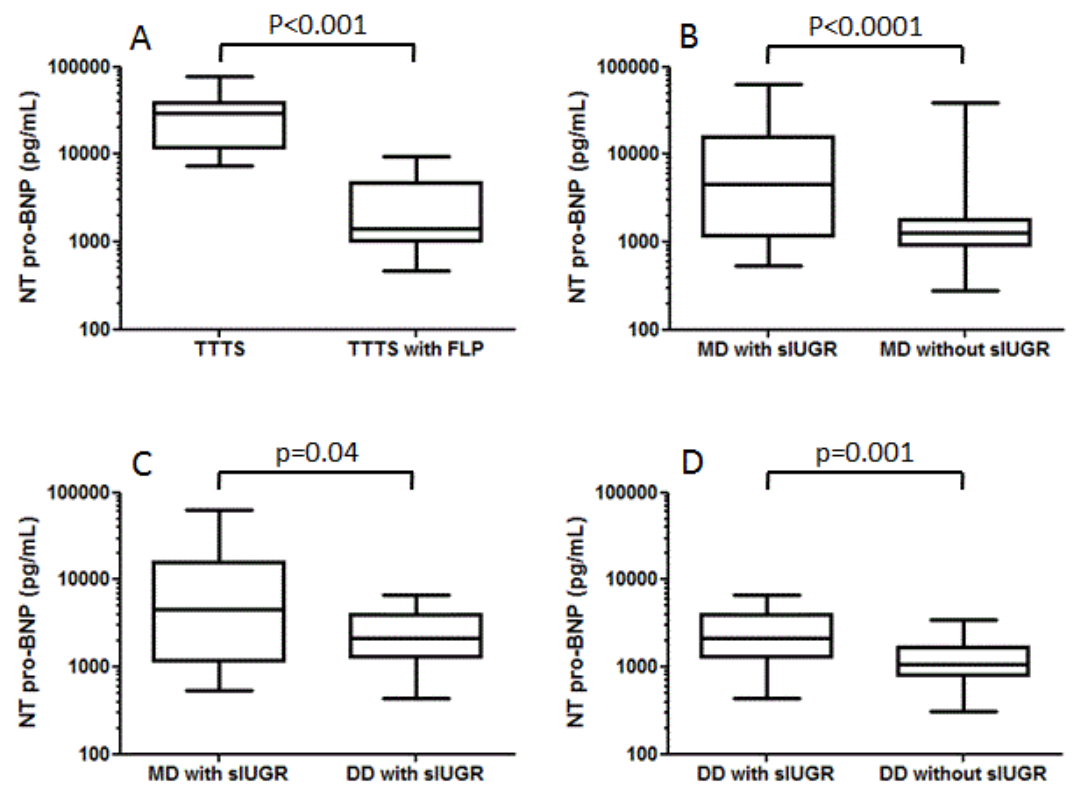

Figure 1: Comparison of NT-pro BNP levels at birth. NT-pro BNP levels at birth were compared between (A) MD twins with TTTS and MD twins with TTTS treated by FLP, (B) MD twins with and without sIUGR, (C) MD twins with sIUGR and DD twins with sIUGR, and (D) DD twins with and without sIUGR. Modified from previous papers by Fujioka et al. [10,46,50].
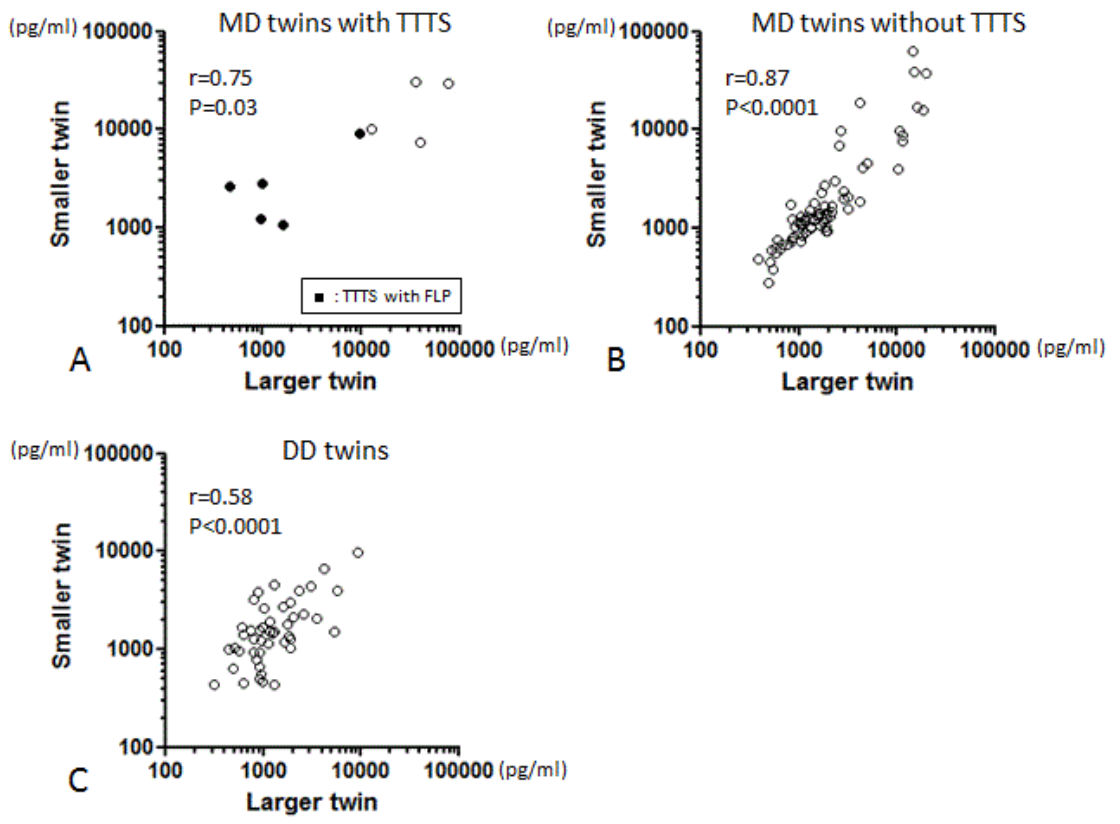

Figure 2: Correlation of NT-pro BNP levels at birth. NT-pro BNP levels at birth were correlated between larger and smaller co-twins in (A) MD twins with TTTS, (B) MD twins without TTTS, and (C) DD twins. Modified from previous papers by Fujioka et al $[10,46,50]$.

proBNP levels at birth in MD twins with sIUGR and DD twins with sIUGR in whom we adapted the same criteria as MD twins [50]. In that comparative study, we found that serum NT-proBNP levels at birth were significantly higher in MD twins with sIUGR than in DD twins with sIUGR ( $4520 \mathrm{pg} / \mathrm{ml}$ [range, 529-62,400 pg/ml] vs. $2115 \mathrm{pg} / \mathrm{ml}$ [range, 443-6590 pg/ml], P=0.04, Figure 1C). In addition, serum NTpro BNP levels at birth were significantly higher in the DD twins with
sIUGR than in the DD twins without sIUGR $(2115 \mathrm{pg} / \mathrm{ml}$ [range, $443-$ $6590 \mathrm{pg} / \mathrm{ml}$ ] vs. $1080 \mathrm{pg} / \mathrm{ml}$ [range, 313-3470 pg/ml], P=0.001, Figure 1D), indicating an effect of IUGR on cardiac load [50]. Furthermore, a significant correlation in serum NT-proBNP levels between smaller and larger co-twins was found in DD twins $(r=0.58, P<0.0001$, Figure $2 \mathrm{C})$, but this was weaker than that in MD twins. Based on these findings, we consider imbalanced feto-fetal transfusion via placental anastomoses 
Citation: Fujioka K, Nakao H (2014) N-Terminal Pro-brain Natriuretic Peptide and Cardiovascular Adaptations in Monochorionic Diamniotic Twins. J Neonatal Biol 3: 124. doi:10.4172/2167-0897.1000124

to be a potential primary cause of postnatal cardiovascular disturbance in MD twins. This implies that the fetal therapy target can be potentially expanded, which is in agreement with the results of a clinical trial with a favorable outcome for sIUGR treated by FLP [51].

\section{Future Directions}

Because we have determined the potential effect of placental vascular anastomoses for postnatal cardiovascular adaptations in non-TTTS MD twins, it is important to determine high risk MD twins without TTTS. In our studies, we have examined MD twins who did not meet the criteria of both TTTS and sIUGR as controls; however, that was not sufficient to eliminate high risk cases from the controls. Since these studies, we have experienced two MD twin cases with severe postnatal circulatory collapse, both requiring intensive treatment. Those cases were assigned to the control group in the previous study [46]. Both of those twins showed a significantly increased intertwin hemoglobin difference $(>8 \mathrm{~g} / \mathrm{dL})$ and increased NT-proBNP levels (1st larger twin: $2580 \mathrm{pg} / \mathrm{ml}$, smaller twin: $6870 \mathrm{pg} / \mathrm{ml}, 2^{\text {nd }}$ larger twin: $14,900 \mathrm{pg} / \mathrm{ml}$, smaller twin: $38,700 \mathrm{pg} / \mathrm{ml}$ ), suggesting twin anemia polycythemia syndrome [28] or acute peripartum TTTS [31] (unpublished data). We consider that these newly proposed entities should be assessed for postnatal cardiovascular adaptations; however their incidence is low and the definition of acute peripartum TTTS is still controversial. Therefore, a multicenter prospective study using an identical definition is desirable to identify other high risk MD twins without TTTS.

\section{Summary}

Based on our observations, we believe the following: (1) MD twins with TTTS show an increased cardiac load at birth and require complete intensive care for both twins for postnatal circulatory collapse, but this is not required for MD twins with TTTS post FLP; (2) MD twins with sIUGR also show mildly increased cardiac load at birth compared with TTTS, and most of them require intensive care for both twins because of poor cardiovascular adaptations; and (3) the reason for an increase in cardiac load in these MD twins could be unbalanced blood transfusion via intertwin vascular anastomoses. Further study is necessary to determine the other high risk MD twin groups, and a novel therapeutic strategy, including fetal therapy, is mandatory to prevent postnatal cardiovascular collapse.

\section{Acknowledgements}

This work was supported by grants for Scientific Research from The Kobe Shinryokukai Association (K.F.).

\section{References}

1. Adegbite AL, Castille S, Ward S, Bajoria R (2004) Neuromorbidity in preterm twins in relation to chorionicity and discordant birth weight. Am J Obstet Gynecol 190: 156-163.

2. Sebire NJ, Snijders RJ, Hughes K, Sepulveda W, Nicolaides KH (1997) The hidden mortality of monochorionic twin pregnancies. Br J Obstet Gynaecol 104 1203-1207.

3. Acosta-Rojas R, Becker J, Munoz-Abellana B, Ruiz C, Carreras E, et al. (2007) Twin chorionicity and the risk of adverse perinatal outcome. Int $\mathrm{J}$ Gynaecol Obstet 96: 98-102.

4. De Paepe ME, Shapiro S, Young L, Luks FI (2010) Placental characteristics of selective birth weight discordance in diamniotic-monochorionic twin gestations. Placenta 31: 380-386.

5. Lewi L, Cannie M, Blickstein I, Jani J, Huber A, et al. (2007) Placental sharing, birthweight discordance, and vascular anastomoses in monochorionic diamniotic twin placentas. Am J Obstet Gynecol 197: 587.

6. Fujioka K, Morioka I, Miwa A, Yokota T, Matsuo K, et al. (2012) Renin is activated in monochorionic diamniotic twins with birthweight discordance who do not have twin-to-twin transfusion syndrome. J Perinatol 32: 514-519.
7. Zhao DP, de Villiers SF, Slaghekke F, Walther FJ, Middeldorp JM, et al (2013) Prevalence, size, number and localization of vascular anastomoses in monochorionic placentas. Placenta 34: 589-593.

8. WAPM Consensus Group on Twin-to-Twin Transfusion, Baschat A, Chmait $\mathrm{RH}$, Deprest J, Gratacós E, et al. (2011) Twin-to-twin transfusion syndrome (TTTS). J Perinat Med 39: 107-112.

9. Quintero RA, Morales WJ, Allen MH, Bornick PW, Johnson PK, et al. (1999) Staging of twin-twin transfusion syndrome. J Perinatol 19: 550-555.

10. Fujioka K, Sakai H, Tanaka S, Iwatani S, Wada K, et al. (2013) N-terminal probrain natriuretic peptide levels in monochorionic diamniotic twins with twin-totwin transfusion syndrome treated by fetoscopic laser photocoagulation. Kobe J Med Sci 59: E28-35.

11. Harkness UF, Crombleholme TM (2005) Twin-twin transfusion syndrome: where do we go from here? Semin Perinatol 29: 296-304

12. Taylor MJ, Govender L, Jolly M, Wee L, Fisk NM (2002) Validation of the Quintero staging system for twin-twin transfusion syndrome. Obstet Gynecol 100: 1257-1265

13. Morine M, Maeda K, Suto M, Kaji T, Irahara M (2005) Intrauterine hemodynamic change in TTTS: the alterations in the inferior vena cava waveform in the donor fetus. Prenat Diagn 25: 1234-1238.

14. Villa CR, Habli M, Votava-Smith JK, Cnota JF, Lim FY, et al. (2013) Assessment of fetal cardiomyopathy in early stage twin-twin transfusion syndrome: Comparison between commonly reported cardiovascular assessment scores. Ultrasound Obstet Gynecol

15. Ishii K, Hayashi S, Nakata M, Murakoshi T, Sago H, et al. (2007) Ultrasound assessment prior to laser photocoagulation for twin-twin transfusion syndrome for predicting intrauterine fetal demise after surgery in japanese patients. Fetal Diagn Ther 22: 149-154.

16. Bajoria R, Ward S, Chatterjee R (2003) Brain natriuretic peptide and endothelin-1 in the pathogenesis of polyhydramnios-oligohydramnios in monochorionic twins. Am J Obstet Gynecol 189: 189-194.

17. Bajoria R, Ward S, Sooranna SR (2001) Atrial natriuretic peptide mediated polyuria: pathogenesis of polyhydramnios in the recipient twin of twin-twin transfusion syndrome. Placenta 22: 716-724.

18. Habli M, Cnota J, Michelfelder E, Salisbury S, Schnell B, et al. (2010) The relationship between amniotic fluid levels of brain-type natriuretic peptide and recipient cardiomyopathy in twin-twin transfusion syndrome. Am J Obstet Gynecol 203: 404.

19. Taylor MJ, Denbow ML, Duncan KR, Overton TG, Fisk NM (2000) Antenatal factors at diagnosis that predict outcome in twin-twin transfusion syndrome. Am J Obstet Gynecol 183: 1023-1028.

20. Kimura Y, Suzuki N, Sugawara J, Murakami T, Terada Y, et al. (2004) Clinical evaluation of the risk of twin-to-twin transfusion syndrome using the relative power contribution of fetal heart rate fluctuations. Fetal Diagn Ther 19: 278-285.

21. Mahieu-Caputo D, Meulemans A, Martinovic J, Gubler MC, Delezoide AL, et al. (2005) Paradoxic activation of the renin-angiotensin system in twin-twin transfusion syndrome: An explanation for cardiovascular disturbances in the recipient. Pediatr Res 58: 685-688.

22. Mahieu-Caputo D, Muller F, Joly D, Gubler MC, Lebidois J, et al. (2001) Pathogenesis of twin-twin transfusion syndrome: the renin-angiotensin system hypothesis. Fetal Diagn Ther 16: 241-244.

23. Moriichi A, Cho K, Furuse Y, Akimoto T, Kaneshi Y, et al. (2013) B-type natriuretic peptide levels are correlated with birth-weight discordance in monochorionic-diamniotic twins without twin-twin transfusion syndrome. J Perinatol 33: 182-187.

24. Leipälä JA, Boldt T, Turpeinen U, Vuolteenaho O, Fellman V (2003) Cardiac hypertrophy and altered hemodynamic adaptation in growth-restricted preterm infants. Pediatr Res 53: 989-993.

25. Merz WM, Kübler K, Fimmers R, Stoffel-Wagner B, Geipel A, et al. (2012) Circulating N-terminal pro-B-type natriuretic peptide in fetal anemia before and after treatment. Pediatr Res 72: 174-178.

26. Gratacos E, Lewi L, Munoz B, Acosta-Rojas R, Hernandez-Andrade E, et al. (2007) A classification system for selective intrauterine growth restriction in monochorionic pregnancies according to umbilical artery doppler flow in the smaller twin. Ultrasound Obstet Gynecol 30: 28-34. 
Citation: Fujioka K, Nakao H (2014) N-Terminal Pro-brain Natriuretic Peptide and Cardiovascular Adaptations in Monochorionic Diamniotic Twins. J Neonatal Biol 3: 124. doi:10.4172/2167-0897.1000124

27. Munoz-Abellana B, Hernandez-Andrade E, Figueroa-Diesel $H$, Ferrer $Q$, Acosta-Rojas R, et al. (2007) Hypertrophic cardiomyopathy-like changes in monochorionic twin pregnancies with selective intrauterine growth restriction and intermittent absent/reversed end-diastolic flow in the umbilical artery. Ultrasound Obstet Gynecol 30: 977-982.

28. Lopriore E, Slaghekke F, Oepkes D, Middeldorp JM, Vandenbussche FP, et al. (2010) Hematological characteristics in neonates with twin anemiapolycythemia sequence (taps). Prenat Diagn 30: 251-255.

29. Lopriore E, Oepkes D, van den Wijngaard JP, van Gemert MJ, Middeldorp JM, et al. (2008) Twin anemia-polycythemia sequence (TAPS) without a cause. Prenat Diagn 28: 559-560.

30. Uotila J, Tammela O (1999) Acute intrapartum fetoplacental transfusion in monochorionic twin pregnancy. Obstet Gynecol 94: 819-821.

31. Lopriore E, Holtkamp N, Sueters M, Middeldorp JM, Walther FJ, et al. (2014) Acute peripartum twin-twin transfusion syndrome: Incidence, risk factors, placental characteristics and neonatal outcome. J Obstet Gynaecol Res 40: 18-24.

32. Fujioka K, Morioka I, Honda S, Tsukahara Y, Miwa A, et al. (2013) Severe retinopathy of prematurity with retinal detachment in monozygotic twins. Pediatr Int 55: 366-368.

33. Lopriore E, Slaghekke F, Vandenbussche FP, Middeldorp JM, Walther FJ, et al. (2008) Cerebral injury in monochorionic twins with selective intrauterine growth restriction and/or birthweight discordance. Am J Obstet Gynecol 199: 628.

34. Ishii K, Murakoshi T, Sago H (2012) Adverse outcome in monochorionic twins with selective intrauterine fetal growth restriction in the presence of abnormal umbilical artery Doppler and severe oligohydramnios. J Obstet Gynaecol Res 38: 1271.

35. Walther T, Stepan H, Faber R (2001) Dual natriuretic peptide response to volume load in the fetal circulation. Cardiovasc Res 49: 817-819.

36. Vanderheyden M, Bartunek, Claeys G, Manoharan G, Beckers JF, et al. (2006) Head to head comparison of $\mathrm{N}$-terminal pro-B-type natriuretic peptide and B-type natriuretic peptide in patients with/without left ventricular systolic dysfunction. Clin Biochem 39: 640-645.

37. Yamada T, Koyama T, Furuta I, Takeda M, Nishida R, et al. (2013) Serum levels of $n$-terminal fragment of precursor protein brain-type natriuretic peptide (nt-probnp) in twin pregnancy. Clin Chim Acta 415: 41-44.

38. Johns MC, Stephenson C (2008) Amino-terminal pro-B-type natriuretic peptide testing in neonatal and pediatric patients. Am J Cardiol 101: 76-81.

39. Moriichi A, Cho K, Mizushima M, Furuse Y, Akimoto T, et al. (2012) B-type natriuretic peptide levels at birth predict cardiac dysfunction in neonates. Pediatr Int 54: 89-93.
40. Bennasar M, Martinez JM, Gomez O, Figueras F, Olivella A, et al.( 2010) Intra- and interobserver repeatability of fetal cardiac examination using fourdimensional spatiotemporal image correlation in each trimester of pregnancy. Ultrasound Obstet Gynecol 35: 318-323.

41. Delabaere A, Marceau G, Kemeny S, Sapin V, Ughetto S, et al. (2010) Intra-amniotic n-terminal pro-brain natriuretic peptide in severe twin-to-twin transfusion syndrome treated by fetoscopic laser coagulation. Ultrasound Obstet Gynecol 35: 620-621.

42. Wagner MM, Lopriore E, Klumper FJ, Oepkes D, Vandenbussche FP, et al. (2009) Short- and long-term outcome in stage 1 twin-to-twin transfusion syndrome treated with laser surgery compared with conservative management. Am J Obstet Gynecol 201: 286.

43. Salomon LJ, Ortqvist L, Aegerter P, Bussieres L, Staracci S, et al. (2010) Long-term developmental follow-up of infants who participated in a randomized clinical trial of amniocentesis vs laser photocoagulation for the treatment of twin-to-twin transfusion syndrome. Am J Obstet Gynecol 203: 444 e441-447.

44. de Haseth SB, Haak MC, Roest AA, Rijlaarsdam ME, Oepkes D, et al. (2012) Right ventricular outflow tract obstruction in monochorionic twins with selective intrauterine growth restriction. Case Rep Pediatr 2012: 426825.

45. Kondo Y, Hidaka N, Yumoto Y, Fukushima K, Tsukimori K, et al. (2010) Cardiac hypertrophy of one fetus and selective growth restriction of the other fetus in a monochorionic twin pregnancy. J Obstet Gynaecol Res 36: 401-404.

46. Fujioka K, Mizobuchi M, Sakai H, Iwatani S, Wada K, et al. (2013) N-terminal pro-brain natriuretic peptide levels in monochorionic diamniotic twins with selective intrauterine growth restriction. J Perinatol. 34: 6-10.

47. Fortunato G, Carandente Giarrusso P, Martinelli P, Sglavo G, Vassallo M, et al. (2006) Cardiac troponin $T$ and amino-terminal pro-natriuretic peptide concentrations in fetuses in the second trimester and in healthy neonates. Clin Chem Lab Med 44: 834-836.

48. Kanbe T, Maeno Y, Fujino H, Kanda H, Hirose A, et al. (2009) Brain-type natriuretic peptide at birth reflects foetal maturation and antenatal stress. Acta Paediatr 98: 1421-1425.

49. Rizzo G, Arduini D (1991) Fetal cardiac function in intrauterine growth retardation. Am J Obstet Gynecol 165: 876-882.

50. Fujioka K, Mizobuchi M, Sakai H, Iwatani S, Wada K, et al. (2014) N-terminal pro-brain natriuretic peptide levels in dichorionic diamniotic twins with selective intrauterine growth restriction. Kobe J Med Sci. in press.

51. Quintero RA, Bornick PW, Morales WJ, Allen MH (2001) Selective photocoagulation of communicating vessels in the treatment of monochorionic twins with selective growth retardation. Am J Obstet Gynecol 185: 689-696. 